\title{
The influence of fencing on seedling establishment during reforestation of oak stands: a comparison of artificial and natural regeneration techniques including costs
}

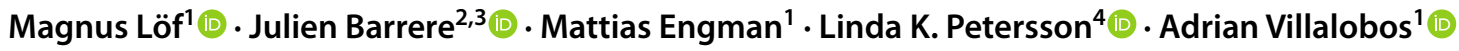

Received: 8 November 2020 / Revised: 3 February 2021 / Accepted: 15 February 2021 / Published online: 1 March 2021

(c) The Author(s) 2021

\begin{abstract}
In temperate Europe, oak-dominated forests are widespread, supporting high biodiversity and providing important ecosystem services. Insufficient natural regeneration has, however, been a concern for over a century. The objective of this study was to gain insights into differences in regeneration success using artificial and natural regeneration techniques for reforestation of oak (Quercus robur L.) stands. We monitored seedlings following planting, direct seeding and natural regeneration over five years in a randomized block experiment in southern Sweden with fenced and non-fenced plots. Fencing had a strong positive effect on height growth, especially for planted seedlings that were taller than the other seedlings and more frequently browsed in non-fenced plots. In contrast, there was little effect of fencing on survival, establishment rate and recruitment rate of seedlings. Due to aboveground damage on seedlings from voles, protection of acorns did not improve establishment rate following direct seeding. Under current circumstances at the site with a sparse shelterwood of old oaks, we conclude that natural regeneration was the most cost-efficient regeneration method. It resulted in the most seedlings at the lowest cost. However, regeneration success was heavily influenced by interference from herbaceous vegetation. With a small additional investment in vegetation control, the results might have been improved for planting and direct seeding.
\end{abstract}

Keywords Competition $\cdot$ Deer $\cdot$ Herbivory $\cdot$ Pedunculate oak $\cdot$ Regeneration method $\cdot$ Silviculture

\section{Introduction}

Pedunculate and sessile oak (Quercus robur L. and Q. petraea (Matt.) Liebl.) are foundational species in European temperate forests where they support more biodiversity than most other tree species (Mölder et al. 2019; Sundberg et al. 2019). Oak forests also provide many ecosystem services

Communicated by Christian Ammer.

Magnus Löf

Magnus.Lof@slu.se

1 Southern Swedish Forest Research Centre, Swedish University of Agricultural Sciences, P.O. Box 49, 23053 Alnarp, Sweden

2 INRAE, UMR SILVA, Université de Lorraine, AgroParisTech, 54000 Nancy, France

3 Direction de La Recherche Et de L'Appui Scientifique, Office Français de La Biodiversité, 01330 Monfort, Birieux, France

4 Swedish Society for Nature Conservation, P.O. Box 4625, 11691 Stockholm, Sweden including quality timber, firewood, forage, recreation, aesthetic/cultural/historical values and watershed protection (Gil-Pelegrín et al. 2017). Additionally, oak forests, because of their high resilience to disturbance and environmental stress, offer a promising alternative for inclusion into management plans addressing increasingly common extreme weather events (Kohler et al. 2020). Sustainable management of oak-dominated forests and habitats is therefore an important issue connected to environmental and land management strategies.

Oak dominance is declining in many parts of the world (Dey et al. 2019), which is particularly concerning in light of their conservation and ecosystem service values. Oak regeneration failures are regarded as central to this problem (Annighöfer et al. 2015). Insufficient natural regeneration of oak has been a concern for over a century (Watt 1919; Korstian 1927). It is well-known that pedunculate and sessile oak are light-demanding species (Röhrig et al. 2006; Ligot et al. 2013; Leuschner and Ellenberg 2018; Kohler et al. 2020). Their regeneration therefore depends on relatively open forests, forest edges or savanna-like grasslands with 
abundant light and natural or anthropogenic disturbances that maintain such habitats (Vera 2000; Bobiec et al. 2018; Petersson et al. 2020). Furthermore, the recruitment strategy of light-demanding temperate tree species such as oaks, growing in open habitats in the presence of thorny shrubs, may be viewed as an adaptation to now extinct large browsers and grazers (Bakker et al. 2004). A distracting fact in many European temperate forests of today is that oaks are among the most palatable tree species for ungulates (Kullberg and Bergström 2010; Petersson et al. 2019). In today's denser and darker environments that lack protective thorny shrubs, grazing and browsing from ungulates may severely affect oak seedling growth and survival (Bobiec et al. 2018; Barrere et al. 2021; Dobrowolska et al. 2020).

Besides light availability, grazing and browsing, acorn dispersal and predation by animals are important for natural regeneration (Mellanby 1968). Scatter-hoarding birds and rodents may consume large quantities of acorns but some will survive and germinate in suitable places (Gómez et al. 2019). Birds in particular can carry acorns far from seedbearing trees to open areas where they may develop successfully (Pesendorfer et al. 2016; Martínez-Baroja et al. 2019).

Open habitats, however, do not guarantee successful establishment in practical forestry. Interference from lowstature herbaceous and woody vegetation may severely reduce growth and survival of young oak seedlings (Jensen et al. 2011). It is often necessary to control competing vegetation using herbicides, mechanical site preparation, mulching or prescribed burning. Numerous studies show a positive correlation between these methods and growth and survival in oak seedlings (e.g., Davies 1988; Löf et al. 2006; Dey et al. 2019). In addition, in habitats with dense herbaceous vegetation, rodents such as voles can damage and consume seedlings which may further reduce survival over time (Manson et al. 2001).

In northern Europe, oak silviculture in pure stands for high-quality timber production combines relatively short rotations (ca 100-130 years) with frequent heavy thinnings and regular high pruning of epicormic branches (Carbonnier 1975; Henriksen 1988). These pure stands are often even aged, with or without an understory of other tree species (Drössler et al. 2012). For various reasons, such stands are considered difficult to regenerate naturally (Löf et al. 1998). For example, acorn removal and consumption by animals, competition from other vegetation and browsing by deer are seen as serious problems (Andersson 1991; Götmark et al. 2005; Jensen et al. 2012). When used, natural regeneration is thought to be most effective following mast years, in a uniform shelterwood system, and sometimes combined with mechanical site preparation (Almgren et al. 1984). However, there are few examples where this method of natural regeneration has been successful (Hansen 1995). Instead, such stands are often clear-cut followed by planting of bare-rooted seedlings, which probably significantly increases the regeneration costs.

This study, conducted in southern Sweden, was designed to examine effects of fencing and regeneration technique (natural regeneration, direct seeding and planting) on the establishment of oak seedlings. To our knowledge, there is a lack of experience from studies where several regeneration techniques are compared side by side, especially for oaks. The objective is to gain practical insight into differences in establishment success using artificial- and naturalregeneration techniques for reforestation of oak stands. To meet this objective, we present findings about the effects of fencing and regeneration technique on the growth, survival, establishment rate and recruitment rate of seedlings. Additionally, we report and discuss the costs involved for the various regeneration techniques used in this study.

\section{Material and methods}

\section{Study site and experimental design}

The experiment was carried in a 2.6 ha oak ( $Q$. robur) stand on the island Visingsö $\left(58.03^{\circ} \mathrm{N}, 14.29^{\circ} \mathrm{E}, 94\right.$ m.a.s.l.) near Gränna in southern Sweden. The island is ca $3 \mathrm{~km}$ wide, $14 \mathrm{~km}$ long with an area of $25 \mathrm{~km}^{2}$. The experiment was initiated in May 2014 and monitored until the autumn of 2018. The stand consisted of a sparse shelter-wood of approximately 100-year-old oaks, without an understory. The mean basal area was $12 \mathrm{~m}^{2} \mathrm{ha}^{-1}$ at the end of the study. This corresponds to ca $42 \%$ of above canopy light in oak forests according to Petersson et al. (2020). In the beginning of the experiment in 2014, the ground vegetation was already dominated by a dense layer of herbaceous vegetation. During the study period, this vegetation was mainly dominated by grasses, sedges and thickets of Rubus idaeus L. In addition, clusters of small naturally regenerated oak seedlings were distributed throughout the stand. These groups of naturally regenerated seedlings were evenly distributed and were estimated to occupy about one third of the area. Only a few individuals of other woody species were present in the seedling/sapling layer. The soil texture of the site is fine sandy till. During the experiment, annual precipitation varied between 331 and $501 \mathrm{~mm}$, and mean air temperature was from -2.1 to $1.8^{\circ} \mathrm{C}$ in January and 15.6 to $20.4{ }^{\circ} \mathrm{C}$ in July (SMHI 2019). Most years had relatively normal rainfall and temperatures except 2018 when there was little precipitation and higher temperatures compared to the mean of the last 20 years (Table 1). Hares (Lepus timidus L. and Lepus europaeus $\mathrm{P}$.) and roe deer (Capreolus capreolus $\mathrm{L}$.) were abundant. There are no figures on population densities available. However, during the period 2014-2018, a yearly average of 25 roe deer were shot on the island, i.e., 10 roe deer 
Table 1 Monthly precipitation $(\mathrm{mm})$ and monthly mean air temperature $\left({ }^{\circ} \mathrm{C}\right)$ during the 2014-2018 growing seasons at Visingsö climate station located $9.6 \mathrm{~km}$ north of the experimental site (SMHI 2019)
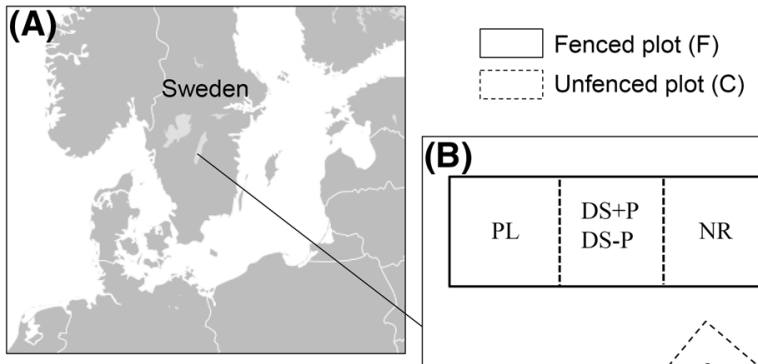

(B)
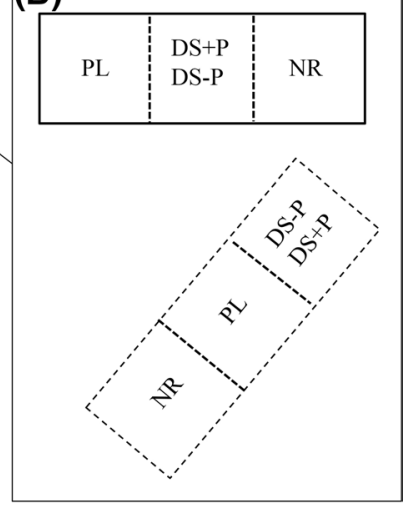

Fig. 1 The location of the site in southern Sweden (a) and an example of design of one out of four blocks (b). Blocks were ca $100 \mathrm{~m}$ apart from each other. Main treatments in each block were the fencing (F) and no fencing (c). The sub-treatments were planting (PL), direct seeding with $(\mathrm{DS}+\mathrm{P})$ and without protection $(\mathrm{DS}-\mathrm{P})$ and natural regeneration $(\mathrm{NR})$

shot per 1000 ha (Hans Christensson pers. comm.). Roe deer annual harvest is a variable positively related to population abundance (Kahlert 2015). No such figures are available for hares. To our knowledge, there were no other large mammals on the island with the potential to damage seedlings.

The experimental design included four randomized blocks with two treatments along with sub-treatments (split plots) in each of the blocks. Figure 1 shows the location of the site and exemplify the design of one out of four blocks (Fig. 1). Blocks were about $100 \mathrm{~m}$ from each other. The treatments were fencing $(\mathrm{F})$ and an unfenced control $(\mathrm{C})$, separated by about 10-20 m within the blocks. Each treatment plot was $8 \times 24 \mathrm{~m}$, and around the F treatment a 2-m-high steel wire fence was erected in May 2014 to exclude large herbivores and hares during the study. Within each block, the two treatment plots were selected so that they were as similar as possible in oak crown coverage and herbaceous species composition. In addition, they were chosen so that a cluster of naturally regenerated oak seedlings was enclosed in each of them. Thus, these naturally regenerated treatment plots were not completely randomized. Each treatment plot was then divided into three subplots $(8 \times 8 \mathrm{~m})$ : planting $(\mathrm{PL})$, direct seeding (DS) and natural regeneration (NR). The NR plots had to be selected to include pre-existing clusters of oak seedlings, whereas the two other plots (PL and DS) were randomly placed in relation to the NR plots. Direct seeding (DS) was done in four rows; two of these rows were randomly selected for direct seeding using an acorn protection device resulting in sub-treatments with (DS $+\mathrm{P})$ and without $(\mathrm{DS}-\mathrm{P})$ seed protection. This device costs 0.30 euro each and consisted of two hollow plastic truncated pyramids joined at the bases which physically protected acorns from removal by rodents (see Castro et al. 2015 for more details). Thus, a total of four sub-treatments were applied (PL, DS + P, DS - P and NR) (Fig. 1).

In the PL plots, bare-rooted oak ( $Q$. robur) seedlings were planted in May 2014. The seedlings were 2 year old, between 30 and $50 \mathrm{~cm}$ tall, originated from Flakulla, Sweden and had not been previously transplanted. The cost per seedling was 0.60 euro (planting procedure excluded). The seedlings were planted manually with a planting auger, at $1 \times 1 \mathrm{~m}$ spacing. In each PL plot, between 46 and 58 seedlings were planted for a total of 419 seedlings in the experiment. The seedlings were obtained from Ramlösa nursery, Sweden.

Due to unavailability of acorns in 2014, direct seeding of Q. robur acorns in the DS plots was carried out in May 2015. Spring seeding is normal practice in the region, although autumn seeding sometimes also occurs. Acorns cost 7.95 euro per $\mathrm{kg}$ (planting procedure of acorns excluded), and there were around 235 acorns per $\mathrm{kg}$ with a vitality of $58 \%$. Acorns were sown at a soil depth of five $\mathrm{cm}$ in four rows that 
were each six m long. We planted two acorns per seeding spot at $20 \mathrm{~cm}$ spacing, which resulted in 120 acorns each in the sub-treatments (two rows each) with and without protection. In total, 960 acorns were sown in the experiment. Acorns were collected in Poland (Puszcza, Barlinecka) in 2014 and stored at Levinsen Treeseed LTD, Lynge, Denmark until use.

\section{Data collection}

For all living planted seedlings, heights (from ground to shoot apex in $\mathrm{cm}$ ) and ground level stem diameter ( $\mathrm{mm}$ ) were measured one, two and five growing seasons following planting (May and October 2015 and October 2018). Before planting, the same variables were measured on a subsample of seedlings $(n=10)$. Due to accidentally driving a truck over one unfenced plot with planted seedlings in 2015, some data were missing in October 2015 and 2018. For all living seedlings produced after direct seeding, heights $(\mathrm{cm})$ were measured one and four growing seasons following seeding (October 2015 and 2018). If two seedlings emerged from the same seeding spot, we measured the tallest one. Heights $(\mathrm{cm})$ of all living naturally regenerated seedlings were measured within one circular plot (radius $2 \mathrm{~m}$ ) on each of the NR plots in May and October 2015 and in October 2018. For all seedlings measured in May and October 2015, we noted if they had been browsed by hares or roe deer (these species' browsing damage is visually similar and was not distinguished). In addition, any other damage (e.g., from voles) that occurred was also noted at the treatment plot scale.

The percentage of ground vegetation (dominated by grasses, sedges and thickets of $R$. idaeus) cover was estimated in all subplots in 40-cm-radius circles close to all the living seedlings in PL and NR plots. In DS plots, vegetation cover was instead measured around the eight plastic sticks that marked the beginning and end of the four rows used for direct seeding. These plots were assigned to one of 11 categories, where $0=0 \%, 1=1-10 \%$ and $10=91-100 \%$ vegetation cover. These measurements were conducted in May and October 2015 and in October 2018.

\section{Calculations and statistical analysis}

\section{Effect of fencing and regeneration technique on seedling height}

Since there were different ages and origins of seedlings in the four regeneration techniques, we evaluated the effect of fencing on height separately for each technique (PL, NR, $\mathrm{DS}-\mathrm{P}$ and $\mathrm{DS}+\mathrm{P}$ ) using linear mixed models. We included two fixed effects: fencing (factor with two modalities: fenced and unfenced) and the date (ordered factor with three levels: May 2015, October 2015 and October 2018), and an interaction between these two fixed effects. The block was included as a random effect. If the fencing date interaction was significant, we tested the differences between fenced and unfenced plots for each sampling year using Tukey's posthoc pairwise comparisons of estimated marginal means.

\section{Effect of fencing and regeneration technique on seedling relative growth rate}

To compare growth of seedlings from the different sub-treatments with different initial heights, we computed relative growth rate (RGR) as:

$\mathrm{RGR}=\frac{H_{\max }\left(\text { Oct2018) }-H_{\max }(\text { Oct2015) }\right.}{H_{\max }(\text { Oct2015) }} \times 100$

$H_{\max }$ is the average of the five tallest seedlings in each subtreatment; this was used since the NR sub-treatment otherwise would have been biased by adding newly recruited (and thus relatively small) seedlings. By using only the five tallest seedlings, we ensure that no newly established seedlings were involved. We then studied the combined effect of the fencing and of the regeneration technique on the RGR with a linear mixed model. We included two fixed effects: fencing and regeneration technique (the latter is a factor with four modalities: PL, DS - P, DS + P and NR), an interaction between these two fixed effects, and the block as a random effect.

\section{Effect of fencing and regeneration technique on survival, establishment rate and recruitment rate}

In the experiment, it was not possible to compare survival rates between sub-treatments. Therefore, for each regeneration technique, we used a different response variable to represent establishment success: survival, establishment rate or recruitment rate. For planted seedlings, we computed survival in plot $\mathrm{k}$, at date $\mathrm{j}$ as:

$\operatorname{Survival}_{j, k}=\frac{n_{\text {seedlings }}(j, k)}{n_{\text {seedlings }}(\text { May2015, } k)} \times 100$

where $n_{\text {seedlings }}(j, k)$ is the number of seedlings in plot $k$ on date $j$ and $n_{\text {seedlings }}$ (May2015,k) is the number of seedlings at start of the experiment in that plot.

As mentioned earlier, in DS plots each seeding point could develop two seedlings where only the tallest was measured. Therefore, in the DS plots we calculated the establishment rate, i.e., the number of seeding points with at least one living seedling in Oct 2018 divided by the initial number of seeding points per sub-treatment in May 2015.

In the NR plots, individual seedlings were not followed. Therefore, for the naturally regenerated seedlings in the NR 
circular survey plots, we computed the number of new seedlings recruited per $\mathrm{m}^{2}$ on date $j$, in plot $k\left(\mathrm{R}_{\mathrm{j}, \mathrm{k}}\right)$ as:

$R_{\mathrm{j}, \mathrm{k}}=\frac{n_{\text {seedlings }}(j, k)-n_{\text {seedlings }}(\text { May2015, } \mathrm{k})}{S_{\mathrm{k}}}$

where $S_{\mathrm{k}}$ is the surface area of the plot $\left(12.57 \mathrm{~m}^{2}\right)$.

We then evaluated the effect of fencing on survival (PL seedlings), establishment rate (DS $-\mathrm{P}$ and $\mathrm{DS}+\mathrm{P}$ ) and recruitment (NR seedlings) with a separate linear mixed model for each regeneration technique. We included fencing, the date and the interaction between these two factors as fixed effects. In each model, the block was included as a random effect. For DS $+\mathrm{P}$ only, we log transformed the establishment rate to meet the assumption that the model residuals are normally distributed. If the fencing date interaction was significant in one of the models, we tested the differences between fenced and unfenced plots for each date using Tukey's post-hoc pairwise comparisons of estimated marginal means.

\section{Effect of regeneration technique on browsing frequency}

In each block and for each date, we calculated the browsing frequency as the number of seedlings browsed divided by the total number of seedlings. We tested the influence of regeneration technique and fencing on browsing frequency with three analyses of variance (ANOVA), one per date: May 2015, October 2015 and October 2018. If the regeneration technique factor or the interaction between regeneration technique and fencing was significant, we assessed the significance of differences among the groups with Tukey's posthoc pairwise comparisons of estimated marginal means.

\section{Regeneration costs}

For fencing costs, we used a standard cost of 11.60 euro per meter (Skogforsk 2020) and assumed that one squareshaped hectare was fenced. In the calculations, we used a standard density of 2800 seedlings or seeding points per ha (Bogghed 2018). We assumed relatively high labour costs for the planting procedure, 1266 euro per ha, since larger bare-rooted seedlings of broadleaves are somewhat more difficult to handle than conifer seedlings (Bogghed 2018). Similarly for direct seedling, we assumed higher labour costs for seeding procedure than normal, 633 euro per ha, since the figures in Bogghed (2018) are based on direct seeding of conifers and not large-seeded species such as Quercus. Due to labour cost of putting the acorns in the protection devices, we doubled the costs when these were included in the DS + P treatment. Except for any fence, no costs were included for natural regeneration, which occupied about one third of the area.
We conducted all analyses in the $\mathrm{R}$ statistical framework, version 3.6.3 (R Core Team 2020). For each model, we verified the Gaussian distribution of the residuals, and the assumption of homogeneity of variance. We performed all linear mixed models with the R package "Ime4" (Bates et al. 2014). We used the "emmeans" $R$ package for Tukey's post-hoc pairwise comparisons of estimated marginal means (Lenth et al. 2018). We examined the significance of the fixed effects of all mixed models with a post-analysis of deviance (Wald $\chi^{2}$ Type II) using the ANOVA function of the R package "car" (Fox et al. 2012). We used an $\alpha=0.05$ significance level for all tests.

\section{Results}

\section{Effects of fencing and regeneration technique on seedling height}

For both PL and NR seedlings, there was a positive effect of fencing on seedling height (Fig. 2). For PL seedlings, this effect $\left(\chi^{2}=37.6, \mathrm{~d} f=1, p<0.001\right)$ increased with time $\left(\chi^{2}=22.3, \mathrm{~d} f=2, p<0.001\right)$. There was also a significant interaction between these two variables $\left(\chi^{2}=38.2, \mathrm{~d} f=2\right.$, $p<0.001)$. By the end of the experiment in October 2018, PL seedlings were $65 \mathrm{~cm}$ tall on average inside fences, whereas unfenced seedlings were $39 \mathrm{~cm}$ tall which is only $2 \mathrm{~cm}$ taller than their original height at the time of planting. The same significant effects were found for stem diameter of PL seedlings (data not shown). Similar effects were also found for NR seedlings. The height of NR seedlings increased with fencing $\left(\chi^{2}=6.61, \mathrm{~d} f=1, p<0.05\right)$ and with time $\left(\chi^{2}=15.79, \mathrm{~d} f=2, p<0.001\right)$, but there was no significant interaction between the two variables $\left(\chi^{2}=3.38, \mathrm{~d} f=2\right.$, $p=0.18$ ). On average, the NR seedlings were smaller than PL seedlings, ranging between 36 (inside fence) and $26 \mathrm{~cm}$ (outside fence) at the end of the experiment. The DS seedlings were even smaller, between 16 and $20 \mathrm{~cm}$ in October 2018. Here, there was a slight but significantly negative effect of fencing on seedling height in the DS-P treatment $\left(\chi^{2}=3.9, \mathrm{~d} f=1, p<0.05\right.$; Fig. 2$)$. Otherwise there were no other significant direct or interaction effects for height of DS seedlings.

\section{Effects of fencing and regeneration technique on seedling relative growth rate}

Except for seedlings in the DS-P treatment, there was a trend toward higher relative growth rate (RGR) in the fenced plots from October 2015 to October 2018 (Fig. 3). This was, however, not significant at the $p<0.05$ level $\left(\chi^{2}=2.71, \mathrm{~d} f=1\right.$, $p=0.1$ ), and there were no significant effects of fencing on RGR in any of the sub-treatments. Neither the effect of the 
Fig. 2 Mean seedling heights following planting (PL), natural regeneration (NR) (top boxes), direct seeding without protection (DS $-\mathrm{P}$ ) and with protection (DS + P) (bottom boxes) from 2014 to 2018 in fenced ( $\mathrm{F}$, gray dots) and unfenced (C, open dots) plots; error bars show $\pm \mathrm{SE}$

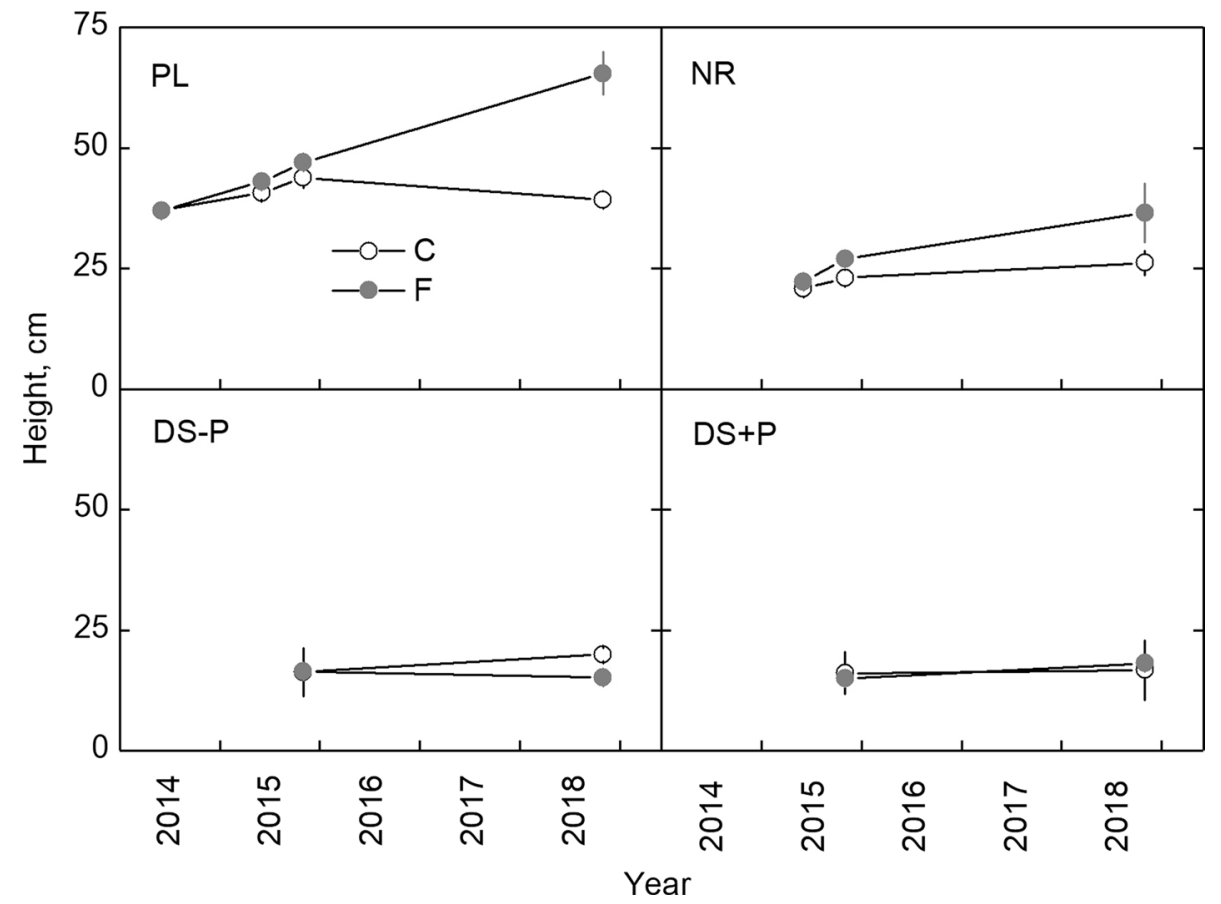

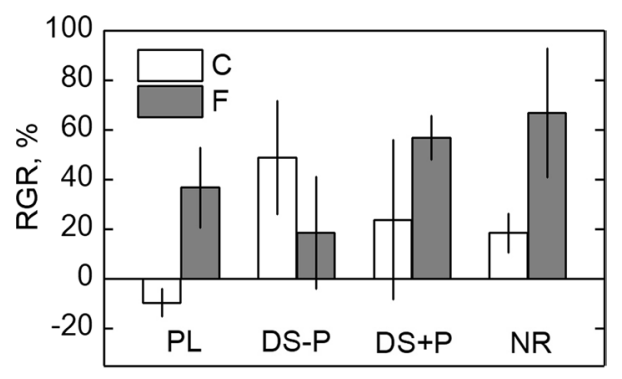

Fig. 3 Relative growth rate (RGR) between 2015 and 2018 of the five tallest seedlings per treatment plot following planting, direct seeding and natural regeneration in fenced (gray bars) and unfenced control plots (open bars) (mean \pm SE)

regeneration technique $\left(\chi^{2}=2.02, \mathrm{~d} f=3, p=0.6\right)$, nor the fencing-regeneration technique interaction $\left(\chi^{2}=4.26, \mathrm{~d} f=3\right.$, $p=0.2$ ) were significant.

\section{Effect of fencing and regeneration technique on survival, establishment rate and recruitment rate}

Survival in PL-seedlings decreased $\left(\chi^{2}=27.4, \mathrm{~d} f=2\right.$, $p<0.001)$ so that survival was ca. $51 \%$ five growing seasons after planting, but there was no effect of fencing $\left(\chi^{2}=0\right.$, $\mathrm{d} f=1, p=0.99$ ) on survival of these seedlings (Fig. 4). Across both DS treatments, the average establishment rate in October 2018 was $21 \%$. However, for the DS - P treatment there were no significant effects of fencing or time, and no significant interaction between the two variables. In contrast, the DS $+\mathrm{P}$ treatment showed a significant interaction between fencing and time $\left(\chi^{2}=6.86, \mathrm{~d} f=1, p<0.01\right)$. In October 2018, the establishment rate was higher in fenced plots than in unfenced plots (Tukey's post hoc test, $p<0.01$ ). From October 2015 to October 2018, we observed a slight trend of increased recruitment of naturally regenerated seedlings $\left(\chi^{2}=2.72, \mathrm{~d} f=1, p=0.1 ;\right.$ Fig. 4$)$. However, there was no effect of fencing on recruitment $\left(\chi^{2}=0.23, \mathrm{~d} f=1\right.$, $p=0.63)$. In October 2018, there were on average 1.9 naturally regenerated seedlings per $\mathrm{m}^{2}$ in our fenced and nonfenced experimental plots (data not shown).

\section{Effect of regeneration technique on browsing frequency}

Browsing damage from roe deer and hare was mainly observed in the unfenced plot. In May 2015, browsing frequency was higher in $\mathrm{C}$ compared to $\mathrm{F}$ plots $(F=48.7$, $\mathrm{d} f=1, p<0.01)$, and with a significant interaction between fencing and regeneration technique: PL seedlings suffered more browsing than NR seedlings $(F=7.1, \mathrm{~d} f=1, p<0.05$; Fig. 5). In October 2015, there was a similar but non-significant trend between $\mathrm{C}$ and $\mathrm{F}$ plots $(F=3.8, \mathrm{~d} f=1, p=0.06)$ but without any interaction or effect of regeneration technique. Browsing frequency was higher in May (on average $38 \%$ ) compared to October 2015 (on average 11\%). In the two first years (2014 and 2015), the lower stems parts of many seedlings were damaged by voles. In addition, we observed many small seedlings established from direct seeding (both inside and outside fences, and from both DS $-\mathrm{P}$ and DS $+\mathrm{P}$ treatments) that were clipped $\mathrm{ca} 1 \mathrm{~cm}$ above the ground, probably by voles. 

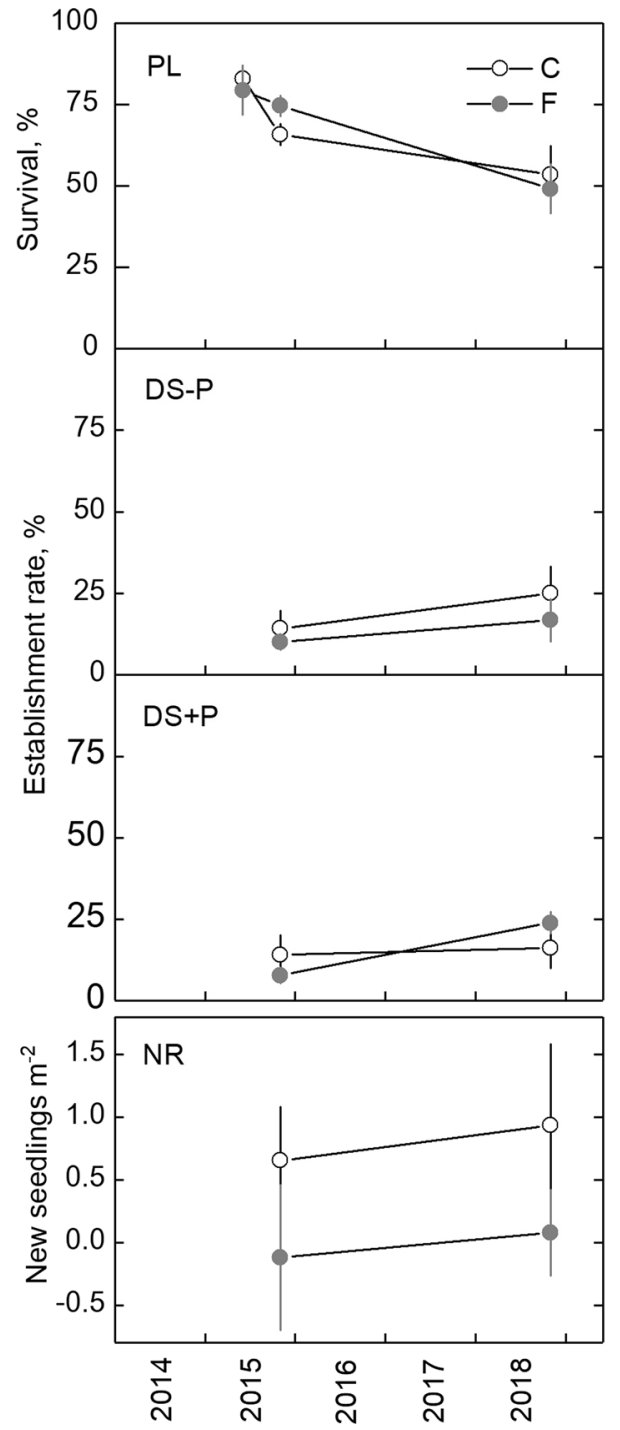

Fig. 4 Mean establishment success represented by different variables for each regeneration technique: survival percentage of planted seedlings (PL) from May 2015 to Oct 2018 (top box), establishment rate in Oct 2015 and 2018 following direct seeding in May 2015 (middle boxes, without and with acorn protection) and number of new naturally regenerated seedlings per square meter during the same period (bottom box). Gray dots show fenced plots and open dots represent unfenced control plots; error bars show standard errors. See Material and Methods for calculations

Throughout the monitoring period of this experiment, there was a high cover (81-90\%) of ground vegetation in all plots (data not shown).

\section{Regeneration costs}

Irrespective of regeneration technique, costs per hectare increased substantially when fencing was included (Table 2). Planting bare-rooted seedlings inside a fence was the most expensive regeneration technique in our study, whereas natural regeneration without fencing cost the least (i.e., no costs). The per-hectare cost of direct seeding without acorn protection or fencing was $28 \%$ of the cost of planting. However, when acorn protection devices were used, the costs increased to $78 \%$ that of planting.

\section{Discussion}

Our results indicate that fencing has a strong positive effect on height growth during the first five years after installation of the experiment, and we found similar trends for diameter growth and relative growth rate (Figs. 2 and 3). This is in line with several other studies on the subject in Europe and elsewhere (e.g. Jensen et al. 2012, Churki et al. 2016, Dey et al. 2019, Ramirez et al. 2020, Petersson et al. 2020, Barrere et al. 2021). In the long run, however, the protective effect from fences can be complicated by competition from other woody vegetation (Leonardsson et al. 2015). Compared to oak seedlings, other woody and faster-growing species that are also protected from browsing inside the fences may then out-compete the young oaks. Thus, growth and survival can also be reduced inside fences. Therefore, and in addition to fencing, management interventions such as pre-commercial thinning may be needed, but in our case few naturally regenerated individuals of other woody species were present.

Although we tested the effect of fencing on height separately for each regeneration technique, our study indicated that the growth benefit of fencing was somewhat stronger for the planted seedlings, which were taller than the naturally regenerated and especially direct-seeded plants. In October 2018, the height differences between seedlings in fenced and unfenced plots were 26,10 and $3 \mathrm{~cm}$ for planted, naturally regenerated and direct-seeded seedlings, respectively. Similar results for oaks were found by Kittredge and Ashton (1995) and Götmark et al. (2005) although their research included browsing from other ungulates. In addition to browsing by roe deer, browsing by moose (Alces alces $\mathrm{L}$.) and to a lesser extent red and fallow deer (Cervus elaphus L., Dama dama L.) occurred in the study of Götmark et al. (2005). They found that young oaks shorter than $20 \mathrm{~cm}$ were much less frequently browsed than taller individuals. In addition, roe deer, as most cervid species, have been shown to preferentially browse near their shoulder's height, i.e., around $75 \mathrm{~cm}$ (Duncan et al. 1998; Nichols et al. 2015) which often results in the observation that small seedlings are less frequently browsed by cervids (Hartley et al. 1997; Renaud et al. 2003). This correlates with our findings in May 2015 of lower browsing frequencies on the small seedlings following natural regeneration (Fig. 5). One important implication from this could be that fencing is not necessary during the first few years of regeneration techniques that 
Fig. 5 Mean browsing frequency on planted (PL), directly seeded (DS) and naturally regenerated seedlings (NR) in May (left box) and Oct (right box) 2015. The DS-P and DS $+\mathrm{P}$ seedlings were not yet established in May 2015, so they aren't shown in the first box. Fenced (gray) and unfenced control plots (open). Error bars show standard errors, and small letters indicate significant differences at $p<.05$

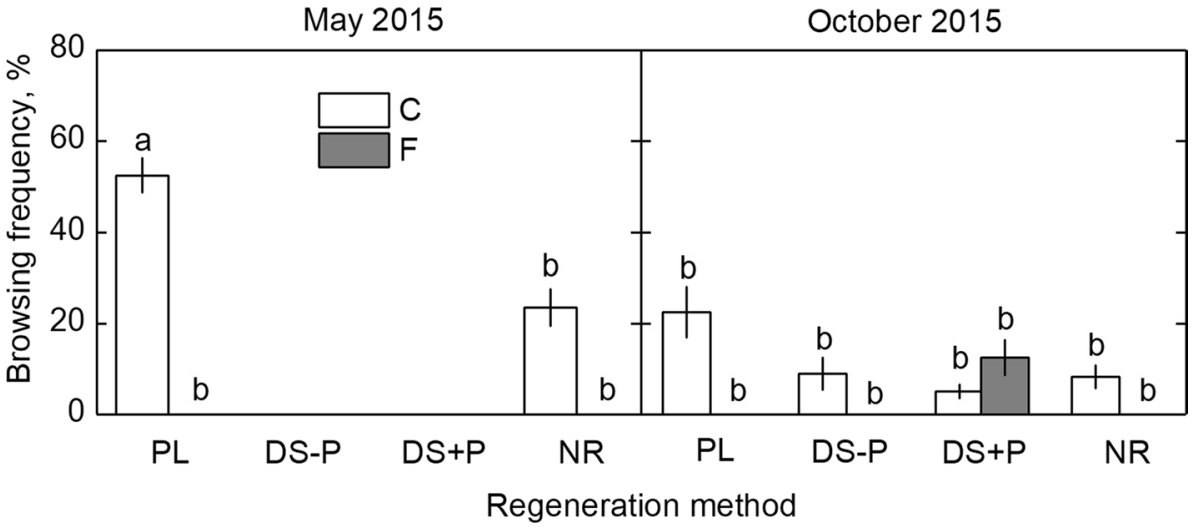

Table 2 Costs (euro ha ${ }^{-1}$ ) in the various treatments and sub-treatments including plant and seed material, any acorn protection devices and fencing and labor costs for planting and direct seeding procedure. For planting and direct seeding, 2800 seedlings or seeding points per hectare have been used for calculations. For description of treatments and costs, see text

\begin{tabular}{lllll}
\hline Treatment & \multicolumn{4}{l}{ Sub-treatment } \\
\cline { 2 - 5 } & PL & DS $-\mathrm{P}$ & DS +P & NR \\
\hline C & 2946 & 823 & 2296 & 0 \\
F & 7586 & 5463 & 6936 & 4640 \\
\hline
\end{tabular}

initially produce small seedlings, i.e., natural regeneration and direct seeding. However, more research is needed before any practical recommendations could be given.

In addition, and in line with previous research in the same region (Petersson et al. 2020), more seedlings in our study seemed to have been browsed during the winter and spring (included in the May measurements) than in the summer and autumn (included in the October measurements). Short et al. (1975) found that the digestibility and nutrient content are optimal during the early spring, which might explain why deer preferentially browse deciduous shoots at that time. However, we only measured browsing frequency during two occasions in 2015, and therefore more observations are needed to support this result.

In contrast to seedling growth, there was little effect of fencing on survival of planted seedlings, establishment rate following direct seeding or on recruitment rate of new naturally regenerated seedlings (Fig. 4). Although oak seedlings in many places are preferentially browsed by ungulates, they are also considered browsing-tolerant because they can survive moderate browsing through re-sprouting (Harmer 2001; Bergqvist et al. 2018; Bobiec et al. 2018). Our experiment was, however, rather short (five years). In the long run, we could probably expect that browsing will reduce survival and establishment and ultimately prevent unprotected seedlings from growing into the overstory (Churki et al. 2016,
Dey et al. 2019). Despite the fact that roe deer may eat large quantities of acorns (Barrere et al. 2020), there was no effect of fencing on the recruitment rate of naturally regenerated seedlings. However, deer mainly consume acorns placed above the soil surface (Garcia et al. 2002). In natural regeneration of oaks, scatter-hoarding animals are often responsible for the dispersal and burial of acorns, and buried acorns face less risk to be consumed by other animals, or to desiccate during dry weather (Watt 1919, Garcia et al. 2002, Bogdziewicz et al. 2020). This may explain why fencing had little effect in our study since small scatter-hoarding animals may search for food and bury acorns both inside and outside fences.

From the start of the experiment herbaceous vegetation cover was close to $90 \%$ in all treatments. Therefore, our results for growth, survival and establishment rates of oak seedlings are heavily influenced by interference from herbaceous vegetation. When oak seedlings of similar initial heights following planting and direct seeding are grown in treatments where herbaceous vegetation is controlled, and in relatively open conditions, they grow taller than in the present study (Davies 1985; Löf et al. 2004). The height of seedlings is, however, not the best indicator of biomass accumulation under these circumstances and most likely underestimates growth reductions due to competition. For example, open-grown oak seedlings tend to invest more resources in roots, branches and leaves compared to height (Jensen et al. 2011). Most likely, seedlings in all our study treatments would have been larger without competing herbaceous vegetation.

The survival rate of planted seedlings at the end of the experiment was only about $50 \%$ (Fig. 4). Similar results have been found in previous research when oak seedlings are planted into already established herbaceous vegetation (Löf et al. 2006). If some form of vegetation control had been applied, the survival would probably have been higher. Abundant natural ground vegetation may decrease soil water content and nutrient availability while exacerbating initial water stress that seedlings undergo following planting (Löf 
et al. 1998). Thus, competing ground vegetation probably weakened the seedlings and partly explains the low survival even though precipitation during the first years following planting was normal. Furthermore, we observed extensive vole damage, possibly causing high mortality during the first years following planting. Earlier research on broadleaved seedling survival and establishment in herbaceous environments has shown that a substantial number of seedlings can be damaged or consumed by rodent herbivores, and thus disappear over time (Lüpke 1987; Manson et al. 2001; Hytönen and Jylhä 2005).

Similar to survival of planted seedlings, the number of established seedlings following direct seeding was rather low. Establishment rates following direct seeding vary due to differences in rodent populations (mice and voles) and the presence of habitats that provide them shelter (Birkedal et al. 2009, 2010). For example, removal rates of buried acorns by rodents correlate with the amount of herbaceous vegetation at the regeneration site (Villalobos et al. 2020). Since we had a high coverage of herbaceous vegetation, it is probable that many acorns were removed before they could germinate. Surprisingly, there was no effect of the acorn protection device. In contrast, Castro et al. (2015) and Leverkus et al. (2015) found that the same device reduced removal significantly to almost zero. Our establishment rates in both DS-treatments were, however, much influenced by the fact that many small seedlings established by direct seeding were clipped about $1 \mathrm{~cm}$ above the ground which even out any differences. This was probably caused by voles since dense herbaceous vegetation is a suitable habitat for voles which feed on plants, seeds and insects (O`Brien 1994, Manson et al. 2001). Especially during winter, they may feed on woody vegetation (Chitty et al. 1968). Therefore, the effect of acorn protection was negligible in this study. Most likely, the acorn protection device would have worked much better in combination with vegetation control or where herbaceous vegetation is not yet established.

What regeneration technique in this study was the most cost effective? (Table 2) When roe deer and hare populations cannot be reduced within a reasonable timeframe, it seems difficult to regenerate oak without fencing. In unfenced areas, seedling height growth was negligible in this study. Thus, and in this region, investing in fences is expensive but necessary as soon as seedlings reach browsing height. The per-hectare cost of direct seeding without acorn protection or fencing was $28 \%$ of the cost of planting. This is somewhat lower compared to figures in Grossnickle and Ivetic (2017). Cost comparisons can differ much depending on the amount of seedlings and acorns used for reforestation. For example and compared to our numbers, many more seedlings and seeding points are often used in central Europe, whereas there are normally much fewer in North America (Röhrig et al. 2006; Dey et al. 2008). In addition, cost comparisons differ due to a number of other factors such as size of seedlings, type of fences and the regeneration conditions such as any need of site preparation and inclination in the terrain etc. Anyway, five years after the start of this experiment, in areas fenced to exclude browsers, planting, direct seeding (without an acorn protection device) and natural regeneration resulted in 1375, 467 and 6333 seedlings per ha, respectively. Not only did natural regeneration produce the highest density of seedlings, it had the lowest cost per ha of any treatment, making it by far the most cost-effective regeneration method. Since many seedlings and saplings eventually die for various reasons, it is important to start with many seedlings during regeneration of oak stands (Kohler et al. 2020). However, in our study the naturally regenerated seedlings were somewhat smaller than the planted ones, and clustered over the area, potentially prolonging the regeneration phase. In addition, where there is more competing woody vegetation, the planted seedlings would likely be more competitive in the beginning. Furthermore, the outcome of planting and direct seeding depend heavily on vegetation control measures. A small additional investment in, for example, mechanical site preparation, might have improved the planting and direct seeding methods.

Acknowledgements The study was supported by the Swedish Research Council for Environment, Agricultural Sciences and Spatial Planning, the Oscar \& Lili Lamms Minne Foundation, the Erik \& Ebba Larsson \& Thure Rignell Foundation and the Professor Lars Tiréns 1958 Donation Fund. We greatly appreciate the fencing and planting work undertaken by the staff of the Swedish National Property Board.

Author contributions ML initiated the study, led the evaluation together with JB and wrote the first draft of the manuscript. ML and LKP prepared material and collected data. JB performed the statistical analysis. All authors contributed to and discussed the previous versions of the manuscript. All authors read and approved the final manuscript.

Funding Open access funding provided by Swedish University of Agricultural Sciences.

\section{Compliance with ethical standards}

Conflict of interest All authors declare that they have no conflict of interest.

Ethical approval This article is distributed under the terms of the Creative Commons Attribution 4.0 International License (http://creativeco mmons.org/licenses/by/4.0/), which permits unrestricted use, distribution and reproduction in any medium, provided you give appropriate credit to the original author(s) and the source, provide a link to the Creative Commons license and indicate if changes were made.

Open Access This article is licensed under a Creative Commons Attribution 4.0 International License, which permits use, sharing, adaptation, distribution and reproduction in any medium or format, as long as you give appropriate credit to the original author(s) and the source, provide a link to the Creative Commons licence, and indicate if changes were made. The images or other third party material in this article are 
included in the article's Creative Commons licence, unless indicated otherwise in a credit line to the material. If material is not included in the article's Creative Commons licence and your intended use is not permitted by statutory regulation or exceeds the permitted use, you will need to obtain permission directly from the copyright holder. To view a copy of this licence, visit http://creativecommons.org/licenses/by/4.0/.

\section{References}

Almgren G, Ingelög T, Ehnström B, Mörtnäs A (1984) Ädellövskog: ekologi och skötsel. Skogsstyrelsen, Jönköping

Andersson C (1991) Distribution of seedlings and saplings of Quercus robur in a grazed deciduous forest. J Veg Sci 2:279-282

Annighöfer P, Beckschäfer P, Vor T, Ammer C (2015) Regeneration patterns of European oak species (Quercus petraea (Matt) Liebl., Quercus robur L.) in dependence of environment and neighborhood. PloS One 10:e0134935

Bakker ES, Olff H, Vandenberghe C, De Maeyer K, Smit R, Gleichman M, Vera FWM (2004) Ecological anachronisms in the recruitment of temperate light-demanding tree species in wooded pastures. $\mathrm{J}$ Appl Ecol 41:571-582

Barrere J, Boulanger V, Collet C, Walker E, Siat V, Henry L, Saïd S (2020) How does oak mast seeding affect the feeding behavior of sympatric red and roe deer? Basic Appl Ecol 47:1-20

Barrere J, Petersson LK, Boulanger V, Collet C, Felton AM, Löf M, Saïd S (2021) Canopy openness and exclusion of wild ungulates act synergistically to improve natural regeneration of oak. For Ecol Manage 487:118976

Bates D, Mächler M, Bolker BM, Walker SC (2014) Fitting linear mixed-effects models using lme4. J Stat Softw 67:1-51

Bergqvist G, Wallgren M, Jernelid H, Bergström R (2018) Forage availability and moose winter browsing in forest landscapes. For Ecol Manag 419-420:170-178

Birkedal M, Fisher A, Karlsson M, Löf M, Madsen P (2009) Rodent impact on establishment of direct seeded beech and oak on forest land. Scand J For Res 24:298-307

Birkedal M, Löf M, Olsson GE, Bergsten U (2010) Effects of granivorous rodents on direct seeding of oak and beech in relation to site preparation and sowing date. For Ecol Manag 259:2382-2389

Bobiec A, Reif A, Öllerer K (2018) Seeing the oakscape beyond the forest: a landscape approach to the oak regeneration in Europe. Landscape Ecol 33:513-528

Bogdziewicz M, Crone EE, Zwolak R (2020) Do benefits of seed dispersal and caching by scatterhoarders outweigh the costs of predation? An example with oaks and yellow-necked mice. J Ecol 108:109-118

Bogghed A (2018) Skogsbrukets kostnader 2018. Norra, mellersta och södra Sverige. Rapport 2018:2, Lantmäteriet

Carbonnier C (1975) Produktionen av kulturbestånd av ek i södra Sverige. Stud For Suec Number 125

Castro J, Leverkus AB, Fuster F (2015) A new device to foster oak forest restoration via seed sowing. New Forest 46:919-929

Chitty D, Pimentel D, Krebs CJ (1968) Food supply of overwintered voles. J Animal Ecol 37:113-120

Churski M, Bubnicki JW, Jedrzejewska B, Kuijper DPJ, Cromsigt JPGM (2016) Brown world forests: Increased ungulate browsing keeps temperate trees in recruitment bottlenecks in resource hotspots. New Phytol 214:158-168

Davies RJ (1985) The importance of weed control and the use of tree shelters for establishing broadleaved trees on grass dominated sites in England. Forestry 58:167-180
Davies RJ (1988) Sheet mulching as an aid to broadleaved tree establishment II: comparison of various sizes of black polythene mulch and herbicide treated spots. Forestry 61:107-124

Dey DC, Jacobs D, McNabb K, Miller G, Baldwin V, Foster G (2008) Artificial regeneration of major oak (Quercus) species in the Eastern United States - a review of the literature. For Sci 54:77-106

Dey DC, Knapp BO, Battaglia MA, Deal RL, Hart JL, O'Hara KL, Schweitzer CJ, Schuler TM (2019) Barriers to natural regeneration in temperate forests across the USA. New Forest 50:11-40

Dobrowolska D, Załuski D, Dąbrowski W, Banul R, Borkowski J (2020) Factors affecting admixed pedunculate oak growth under heavy browsing by deer: benefits from inter- and intraspecific neighborhoods. Europ J For Res 139:155-167

Drössler L, Attocchi G, Jensen AM (2012) Occurrence and management of oak in southern Swedish forests. Forstarchiv 83:163-169

Duncan P, Tixier H, Hoffman RR, Lechner-Doll M (1998) Feeding strategies and the physiology in roe deer. In: Andersen R, Duncan P, Linnell JDC (eds) The European roe deer: the biology of success. Scandinavian University Press, Oslo, pp 91-116

Fox J, Weisberg S, Adler D, Bates D, Baud-bovy G, Ellison S, Firth D, Friendly M, Graves S, Heiberger R, Laboissiere R, Monette G, Murdoch D, Nilsson H, Ogle D, Ripley B, Venables W, Winsemius D, Zeleis A (2012) Package 'car.' R Foundation for Statistical Computing, Vienna, pp 1-171

García D, Bañuelos MJ, Houle G (2002) Differential effects of acorn burial and litter cover on Quercus rubra recruitment at the limit of its range in eastern North America. Can J Bot 80:1115-1120

Gil-Pelegrín E, Peguero-Pina JJ, Sancho-Knapik D (2017) Oak physiological ecology. Exploring the functional diversity of genus Quercus L. Springer, Tree Physiology 7

Gómez JM, Schupp EW, Jordano P (2019) Synzoochory: the ecological and evolutionary relevance of a dual interaction. Biol Rev 94:874-902

Götmark F, Berglund Å, Wiklander K (2005) Browsing damage on broadleaved trees in semi-natural temperate forest in Sweden, with focus on oak regeneration. Scand J For Res 20:223-234

Grossnickle SG, Ivetić V (2017) Direct seeding in reforestation: a field performance review. Reforesta 4:94-142

Hansen K (1995) Naturlig föryngring av ek. SLU, Skogsmästarskolan, Examensarbete 1995

Harmer R (2001) The effect of plant competition and simulated summer browsing by deer on tree regeneration. J Appl Ecol 38:1094-1103

Hartley SE, Lason GR, Duncan AJ, Hitchcock D (1997) Feeding behaviour of red deer (Cervus elaphus) offered Sitka Spruce saplings (Picea sitchensis) grown under different light and nutrient regimes. Funct Ecol 11:348-357

Henriksen H A (1988) Skoven og dens dyrkning. Nyt nordisk forlag Arnold Busck, Köbenhavn

Hytönen J, Jylhä P (2005) Effects of competing vegetation and postplanting weed control on mortality, growth and vole damages to Betula pendula planted on former agricultural land. Silva Fennica 39:365-380

Jensen AM, Löf M, Gardiner ES (2011) Effects of above- and belowground competition from shrubs on photosynthesis, transpiration and growth in Quercus robur L. Environ Exp Bot 71:367-375

Jensen AM, Götmark F, Löf M (2012) Shrubs protect oak seedlings against ungulate browsing in temperate broadleaved forests of conservation interest: a field experiment. For Ecol Manag 266:187-193

Kahlert J, Fox AD, Heldbjerg H, Asferg T, Sunde P (2015) Functional responses of human hunters to their prey: why harvest statistics may not always reflect changes in prey population abundance. Wildlife Biol 21:294-302

Kittredge DB, Ashton PMS (1995) Impact of deer browsing on regeneration in mixed stands in southern New England. North J Appl For 12:115-120 
Kohler M, Pyttel P, Kuehne C, Modrow T, Bauhus J (2020) On the knowns and unknowns of natural regeneration of silviculturally managed sessile oak (Quercus petraea (Matt.) Liebl.) forests: a review. Ann Sci 77:101

Korstian, C.F. 1927. Factors Controlling Germination and Early Survival in Oaks. Yale School of Forestry Bulletin 19

Kullberg Y, Bergström R (2001) Winter browsing by large herbivores on planted deciduous seedlings in Southern Sweden. Scand J For Res 16:371-378

Lenth R V (2018) Emmeans: Estimated marginalmeans, aka leastsquares means. R package version1.1. Retrieved from https:// cran.r-project.org/web/packages/emmeans/index.html

Leonardsson J, Löf M, Götmark F (2015) Exclosures can favour natural regeneration of oak after conservation-oriented thinning in mixed forests in Sweden: a 10-year study. For Ecol Manag 354:1-9

Leuschner C, Ellenberg H (2018) Ecology of central European forests. Springer, Germany

Leverkus AB, Rojo M, Castro J (2015) Habitat complexity and individual acorn protectors enhance the post-fire restoration of oak forests via seed sowing. Ecol Eng 83:276-280

Ligot G, Balandier P, Fayolle A, Lejeune P, Claessens H (2013) Height competition between Quercus petraea and Fagus sylvatica natural regeneration in mixed and uneven-aged stands. For Ecol Manag 304:391-398

Löf M, Nilsson U, Gemmel P, Welander NT (1998) The influence of site preparation on growth in Quercus robur L. seedlings in a southern Sweden clear-cut and shelterwood. For Ecol Manag 109:241-249

Löf M, Thomsen A, Madsen P (2004) Sowing and transplanting of broadleaves (Fagus sylvatica L., Quercus robur L., Prunus avium L. and Crataegus monogyna Jacq.) for afforestation of farmland. For Ecol Manag 188:113-123

Löf M, Rydberg D, Bolte A (2006) Mounding site preparation for forest restoration: Survival and growth response in Quercus robur L. seedlings. For Ecol Manag 232:19-25

Manson RH, Ostfeld RS, Canham CD (2001) Long-term effects of rodent herbivores on tree invasion dynamics along forest-field edges. Ecology 82:3320-3329

Martínez-Baroja L, Pérez-Camacho L, Villar-Salvador P, Rebollo S, Quiles P, Gómez-Sánchez D, Molina-Morales M, Leverkus AB, Castro J, Rey-Benayas JM (2019) Massive and effective acorn dispersal into agroforestry systems by an overlooked vector, the Eurasian magpie (Pica pica.). Ecosphere 10:e02989

Mellanby K (1968) The effects of some mammals and birds on regeneration of oak. J Appl Ecol 5:359-366

Mölder A, Meyer P, Nagel R-V (2019) Integrative management to sustain biodiversity and ecological continuity in Central European temperate oak (Quercus robur, Q. petraea) forests: an overview. For Ecol Manag 437:324-339

Nichols RV, Cromsigt JPGM, Spong G (2015) DNA left on browsed twigs uncovers bite-scale resource use patterns in European ungulates. Oecologia 178:275-284
O'Brien J M (1994) Voles, The Handbook: Prevention and Control of Wildlife Damage. 23. University of Nebraska, Lincoln

Pesendorfer MB, Sillett TS, Koenig WD, Morrison SA (2016) Scatterhoarding corvids as seed dispersers for oaks and pines: A review of a widely distributed mutualism and its utility to habitat restoration. Condor 118:215-237

Petersson LK, Milberg P, Bergstedt J, Dahlgren J, Felton AM, Götmark F, Salk C, Löf M (2019) Changing land use and increasing abundance of deer cause natural regeneration failure of oaks: six decades of landscape-scale evidence. For Ecol Manag 444:299-307

Petersson LK, Dey DC, Felton AM, Gardiner ES, Löf M (2020) Influence of canopy openness, ungulate exclosure, and low-intensity fire for improved oak regeneration in temperate Europe. Ecol Evol $10: 2626-2637$

R Core Team (2020) R Core Team R: A language and environment for statistical computing $\mathrm{R}$ foundation for statistical computing, Austria, Vienna

Renaud PC, Verheyden-Tixier H, Dumont B (2003) Damage to saplings by red deer (Cervus elaphus): effect of foliage height and structure. For Ecol Manag 181:31-37

Röhrig E, Bartsch N, Lüpke B (2006) Waldbau auf ökologischer Grundlage. Eugen Ulmer Verlag, Stuttgart

Short HL, Blair RM, Epps EA Jr (1975) Composition and digestibility of deer browse in southern forests. Forest Service Research Paper, New Orleans

Skogforsk (2020) Skogskunskap. www.skogskunskap.se. Accessed 2020-08-28.

SMHI (2019) Swedish Meteorological and Hydrological Institute. Retrieved from https://www.smhi.se/data

Sundberg S, Carlberg T, Sandström J, Thor G (Eds.) (2019) Värdväxters betydelse för andra organismer: med fokus på vedartade värdväxter. ArtDatabanken Rapporterar 22. ArtDatabanken SLU, Uppsala

Vera FWM (2000) Grazing ecology and fire history. CABI Publishing, Wallingford

Villalobos A, Schlyter F, Olsson G, Witzell J, Löf M (2020) Direct seeding for restoration of mixed oak forests: influence of distance to forest edge, predator-derived repellent and acorn size on seed removal by granivorous rodents. For Ecol Manag 477:118484

von Lüpke B (1987) Einflüsse von Altholzüberschirmung und Bodenvegetation auf das Wachstum jünger Buchen und Traubeneichen. Forstarchiv 58:18-24

Watt AS (1919) On the causes of failure of natural regeneration in British oakwoods. J Ecol 7:173-203

Publisher's Note Springer Nature remains neutral with regard to jurisdictional claims in published maps and institutional affiliations. 